Saudi Journal of Business and Management Studies Abbreviated Key Title: Saudi J Bus Manag Stud ISSN 2415-6663 (Print) |ISSN 2415-6671 (Online) Scholars Middle East Publishers, Dubai, United Arab Emirates Journal homepage: http://scholarsmepub.com/sjbms/

Original Research Article

\title{
The Analysis of the Board of Directors and the Board of Commissioners to Increase Profitability in the 5 Biggest Sharia Commercial Banks in Indonesia
}

\author{
Kurniawan \\ Accounting Department, Faculty of Economics and Business, Siliwangi University, Jl. Siliwangi No.24, Kahuripan, Kec. Tawang, Tasikmalaya, Jawa \\ Barat 46115, Indonesia
}

DOI: $10.36348 /$ sjbms.2020.v05i01.004
*Corresponding author: Kurniawan

| Received: 01.01.2020 | Accepted: 10.01.2020 | Published: 18.01 .2020

\section{Abstract}

Good corporate governance is needed to improve the performance of a bank, especially Sharia banks. The mechanism of good governance is the existence of a board of directors as executors of management and a board of commissioners as supervisors. This study aims to analyze the influence of the board of directors and the board of commissioners in improving financial performance. The study was conducted on 5 sharia commercial banks from 2013 to 2018 which had the largest assets using secondary data. The method used is a quantitative analysis using multiple regression. The results showed that the board of directors did not have a significant influence on financial performance, while the board of commissioners had a negative influence on the financial performance of Sharia commercial banks in Indonesia.

Keywords: Financial performance, Sharia bank, good corporate governance.

Copyright @ 2020: This is an open-access article distributed under the terms of the Creative Commons Attribution license which permits unrestricted use, distribution, and reproduction in any medium for non-commercial use (NonCommercial, or CC-BY-NC) provided the original author and source are credited.

\section{BACKGROUND}

Public awareness of using Islamic finance continues to grow, so to improve its services must be followed by increased ease of access to Islamic finance and improving the quality of its management. If the sharia economic potential is developed continuously, Indonesia will be optimistic that it will become the center of sharia financial development at the world level. Thus, Sharia banking must have good performance as capital in competing with conventional banking.

Actually, Sharia banking has been able to prove that in the past crisis, Islamic finance became a solution to strengthen the community's economy, so it is important to continue to maintain the growth of Islamic finance in order to be able to encourage the acceleration of national economic growth.

But to maintain that, the Sharia banking industry must have a good performance that will show that Sharia banking still has the power to compete. Therefore, it is important to maintain the performance of Sharia banking, many researchers have discovered the factors that influence financial performance through different models.

From the initial data obtained, the average financial performance of Sharia banks through profitability ratios (return on assets / ROA) can be seen in Figure-1. 


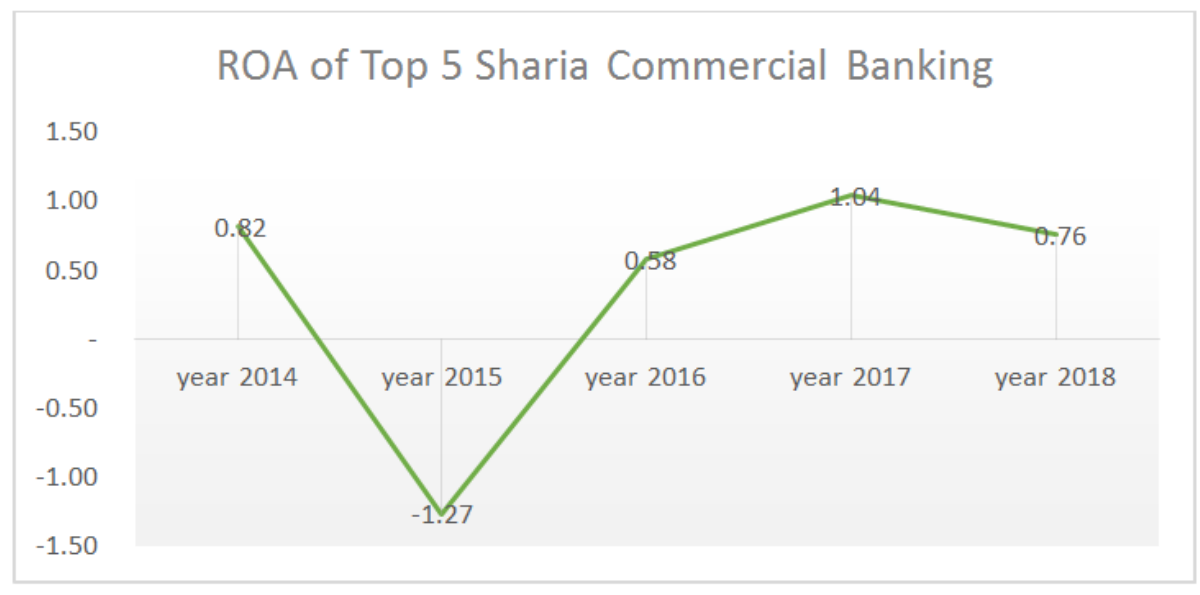

Fig-1: Average ROA of the Top 5 Sharia Commercial Banks in 2014-2018

Figure-1 shows that the average profitability of some of the largest Sharia banks in Indonesia fluctuates considerably so that the performance obtained every year is quite inconsistent. Therefore it is important to find the best way to solve the problem.

In this study, there is a very important thing to study to find evidence that good governance is a factor that determines the performance of Sharia banks. According to Chapra and Umar that management and supervision functions which are part of the mechanism of good corporate governance and need to be carried out properly, so that the functions of the board of directors and the board of commissioners need to be optimized in order to achieve business success because it will controlling the potential of resources owned by Sharia banks [1].

The board of directors and the board of commissioners are a form of good corporate governance mechanism that has different functions. The board of directors functions as a manager, and regulates the company's operations, including human resource management, and finance, while the board of commissioners is tasked with overseeing the operations of the bank so that it stays in accordance with established goals and runs according to the rules. Both have the same goals but have different tasks, but ultimately aim to improve the performance of Sharia banks. This is based on several (empirical) studies that have been done previously that good corporate governance basically aims to improve the performance of a company.

Based on the background above, this study has the following objectives:

- Knowing the influence of the number of boards of directors on the financial performance of Sharia banking

- Knowing the influence of the number of board of commissioners on the financial performance of Sharia banking

\section{LITERATURE REVIEW Sharia bank}

The definition of a bank according to RI Law number 10 of 1998 concerning banking, that what is meant by a bank is a business entity that collects funds from the public in the form of deposits and distributes them to the public in the form of credit and or other forms in order to improve the lives of many people [2]. Whereas Sharia Bank is a bank with a banking system that runs its business operations based on the concept of division, both profits and losses, so that the results obtained by customers will fluctuate according to the profits obtained by the bank where the greater the bank's profits, the greater the results obtained by customers. Sharia banks are developed on the principle that there should be no separation between religious and temporal matters. So according to Karim that this principle requires adherence to Islamic law as the basis of all aspects of life [3]. This compliance is carried out not only in the form of ritual worship, but business transactions must be in accordance with Islamic teachings. By that kanre, Sharia banks reject interest as a fee for the use of money and loans as an investment tool.

Because Sharia banks are intermediary institutions from those who need funds with those who have funds, Sharia banks have a strategic role in the country's economic growth. This role causes the operational continuity of a bank to be maintained. In order to carry out its functions properly, Sharia banks must maintain their performance.

\section{Good Corporate Governance Mechanism as a Factor Affecting Banking Profitability}

Corporate governance is intended to regulate the course of the company and control it to create added value for the company itself in order to provide benefits for all parties involved. Corporate governance is also governance that regulates the relationship between internal parties and external parties including the government and the community. 
According to the Decree of the Head of the Investment and Development Board of BUMN No. 23/M-PM.PBUMN/2000 concerning the development of good corporate governance practices in the Company, explains that good corporate governance (GCG) is a sound corporate principle that needs to be applied in managing a company that is carried out solely in order to safeguard the interests of the company in order to achieve the company's goals and objectives.

Therefore, management is a very important factor in running an Sharia bank, so good corporate governance needs to be run as well as possible. All levels of bank management, including those covering asset quality, capital management, liquidity management, profitability management, and general management, will ultimately determine the bank's profitability in order to increase profitability. Furthermore, to improve the quality of management, Sharia banks must implement the mechanism of good corporate governance (GCG) as well as possible, because GCG is a factor that provides an influence in improving the financial performance of Sharia banks, especially variable CGC mechanism consisting of the number of boards of directors and the number of boards commissioner. Associated with practice that occurs in the field is the more boards of directors, the more variety of opinions that can encourage increased company performance, but the opposite condition can occur that the more boards of directors there will be a lot of interests that disrupt corporate performance. Rahardja's research results on manufacturing companies show that the board of directors has a positive influence on financial performance [4], as well as Rahmawati, et al showing that the board of directors has a positive influence on the financial performance of a Coal Mining company [5].

Other facts on the ground that management policies in running a company are certainly quite influenced by the presence of the board of commissioners in overseeing their work. According to Chtourou et al that the greater the number of boards, the better the monitoring mechanism of company management [6]. However, in practice, there are job irregularities that can interfere with company performance, even though the board of commissioners has the duty to keep the company from leaving operational procedures with the aim that the company has good performance. This condition must trigger the company that management should be encouraged to work better through the supervision of the board of commissioners. As in the research of Rahmawati et al., [5] and Hidayat and Firmansyah [7] that the board of commissioners has a positive influence on improving the company's financial performance. However, it is different from Rahardja's [4] and Putra's [8] research that the number of boards of commissioners does not have a significant influence in improving financial performance.
Overall, Klapper and Love's research found that there is a positive relationship between corporate governance and company performance [9]. The explanation shows that the board of directors and the board of commissioners are factors that contribute to the management's role in running the business. Therefore, the hypotheses built are:

H1: the number of board of directors has a positive effect on the profitability of Sharia commercial banks

$\mathrm{H} 2$ : the number of the board of commissioners has a positive effect on the profitability of Sharia banks

\section{METHODOLOGY \\ Population and Sample}

This study uses the population of all Sharia banks in Indonesia. From the entire population, a purposive sampling method was used to select the sample that will be used in this study with the specified criteria, namely 1) Sharia commercial banks that have financial reports published on their respective websites with a span of periods between 2014 and 2018, and 2 ) Sharia commercial banks that have 5 large assets.

\section{Research Variables}

This study uses 2 types of variables, namely:

1. Independent variable, which is a mechanism of good corporate governance consisting of:

a. Board of Directors, i.e. the number of boards of directors tasked with leading the operation of the sharia bank

b. Board of Commissioners, i.e. the number of commissioners serving as supervisors for the operation of the sharia bank.

2. Dependent Variable, namely financial performance as measured by return on assets (ROA). ROA is often used as a measure of financial performance by Bank Indonesia so this ratio is often used by researchers.

\section{DATA ANALYSIS METHODS}

At this stage a regression analysis will be conducted to find answers to the objectives of this study, including multiple regression analysis, moderation regression analysis, and simple regression analysis. The basic model of ordinary least square (OLS) multiple regression analysis can be formulated as follows:

$$
\mathrm{ROA}=\mathrm{a}+\boldsymbol{\beta}_{1} \mathrm{Dir}+\boldsymbol{\beta}_{2} \mathrm{Com}+\mathrm{e}
$$

Before analyzing the research model above, the data quality test is performed using the classic assumption test which consists of a normality test, a multicollinearity test and a heteroscedasticity test. To analyze this regression model using SPSS software. 
Kurniawan; Saudi J Bus Manag Stud, Jan., 2020; 5(1): 26-31

\section{RESULTS AND DISCUSSION}

The results of data collection in accordance with the required criteria, obtained the 5 largest Sharia commercial banks, namely Muamalat Bank, BNI Syariah, BRI Syariah, Bank Mandiri Syariah, and Panin Syariah Bank.

\section{Classic Assumption Test}

The first step is testing the quality of the data to meet the classical assumptions to ensure that the data can be used for regression analysis. The results of the analysis can be seen in Table-1.

Table-1: Normality Test

\begin{tabular}{|l|l|l|}
\hline \multicolumn{2}{|c|}{} & Unstandardized Residual \\
\hline $\mathrm{N}$ & Mean & 29 \\
\cline { 2 - 3 } Normal Parameters & Std. Deviation &, 0000000 \\
\hline \multirow{3}{*}{ Most Extreme Differences } & Absolute &, 088 \\
\cline { 2 - 3 } & Positive &, 060 \\
\cline { 2 - 3 } & Negative &,- 088 \\
\hline \multicolumn{2}{|l|}{ Test Statistic } &, 088 \\
\hline Asymp. Sig. (2-tailed) &, 200 \\
\hline
\end{tabular}

Source: SPSS output

This test is used to determine whether the independent and dependent variables in the regression model have a normal distribution or not. To find out, the Kolmogorov-Smirnov test was carried out. If the Asymp value. Sig (2-tailed) is greater than 0.05, then the data are declared normally distributed.

Based on SPSS output that the significance value is 0.200 . This value is greater than 0.05 , so it can be concluded that the data is stated to be normally distributed and the data is feasible to use because it can be said that the regression model meets the normality assumption.

Table-2: Multicollinearity Test

\begin{tabular}{|c|l|l|l|}
\hline \multicolumn{2}{|l|}{ Model } & \multicolumn{2}{|l|}{ Collinearity Statistics } \\
\cline { 3 - 4 } \multicolumn{2}{|c|}{1} & Tolerance & VIF \\
\hline \multirow{2}{*}{1} & (Constant) & & \\
\cline { 2 - 4 } & Com &, 800 & 1,250 \\
\cline { 2 - 4 } & Dir &, 800 & 1,250 \\
\hline
\end{tabular}

Source: SPSS output

The second test is the multicollinearity test. This test is intended to determine whether there is a perfect intercorrelation between the independent variables used in this study. This test is done with Tolerance Value and Variance Inflation Factor (VIF). To avoid multicollinearity, the Tolerance Value limit> 0.1 and VIF <10. The results of the multicollinearity test analysis show that the VIF value of all independent variables consisting of the board of directors and the board of commissioners is less than 10 (around the number 1). And the value of tolerance (TOL) obtained shows a value greater than 0.10 . Therefore, it can be seen that the regression model is free from multicollinearity between independent variables.

The third test is autocorrelation. This test aims to test whether in the linear regression model there is a correlation between the error of the intruder in period $t$ with the previous error (period t-1). If there is a correlation, it is called an autocorrelation problem. This problem arises because consecutive observations over time (time series) are related to each other. A good regression model is free from autocorrelation.

Table-3: Autocorrelation Test

\begin{tabular}{|l|l|}
\hline Model & Durbin-Watson \\
\hline 1 & 1,559 \\
\hline
\end{tabular}

Source: SPSS output

Based on the results of the autocorrelation regression analysis of the Durbin Watson (DW) value of 2,076. Whereas based on the Durbin Watson (DW) table with $\mathrm{k}=2$ and $\mathrm{n}=30$, the value of $\mathrm{dL}=1.28$ and $\mathrm{dU}=1.57$, then $4-\mathrm{dU}=2.43$ and $4-\mathrm{dL}=2.72$. Therefore the DW value is between $\mathrm{dU}$ and $4-\mathrm{dU}$ so that the conclusion can not be autocorrelated.

Table-4: Heteroscedasticity Test

\begin{tabular}{|l|l|c|}
\hline \multicolumn{2}{|c|}{ Model } & Sig. \\
\hline \multirow{3}{*}{1} & (Constant) &, 010 \\
\cline { 2 - 3 } & Com &, 516 \\
\cline { 2 - 3 } & Dir &, 420 \\
\hline
\end{tabular}

Source: SPSS output

To find out the presence or absence of heteroscedasticity, the Glejser Test is used. The test results found that the significance value of all independent variables is greater than 0.05 . So it can be concluded in the regression model in this study that there are no symptoms of heteroscedasticity.

\section{Multiple Regression Analysis}

After all the data have been declared good, proceed with multiple regression analysis. At this stage the effect of the number of boards of directors and the number of boards of commissioners will be tested on the financial performance of Sharia banks. 
Table-5: $\mathbf{R}$ and $\mathbf{F}$ tests

\begin{tabular}{|l|l|l|l|l|l|l|}
\hline \multicolumn{2}{|l|}{ Model } & R & R Square & Adjusted R Square & F & Sig. \\
\hline \multirow{4}{*}{1} &, $502^{\mathrm{a}}$ &, 252 &, 195 & 4,390 &, $023^{\mathrm{b}}$ \\
\cline { 2 - 7 } & Residual & & & & & \\
\cline { 2 - 7 } & Total & & & & & \\
\hline
\end{tabular}

Source: SPSS output

The above output explains that the influence resulting from the mechanism of good corporate governance (GCG) through the number of boards of directors and the number of boards of commissioners on performance is 0.252 or $25.2 \%$ and the remaining $74.8 \%$ is influenced by other factors not examined.
Meanwhile, the significance value of the $\mathrm{F}$ test was 0.023 so that it was significant at the $5 \%$ level. This value below 0.05 indicates that the number of boards of directors and the number of boards of commissioners can be used to predict profitability, so this research is worth continuing to find out which variable most determines the profitability of Sharia commercial banks.

Table-6: t-Test

\begin{tabular}{|c|l|l|l|l|l|l|}
\hline \multicolumn{2}{|l|}{ Model } & \multicolumn{2}{|l|}{ Unstandardized Coefficients } & Standardized Coefficients & \multirow{2}{*}{ S } & \multirow{2}{*}{ Sig. } \\
\cline { 3 - 7 } \multicolumn{2}{|c|}{1} & B & Std. Error & Beta & & \\
\hline \multirow{2}{*}{1} & (Constant) & 2,176 &, 497 & & 4,378 &, 000 \\
\cline { 2 - 7 } & Com &,- 228 &, 108 &,- 400 & $-2,110$ &, $045^{*}$ \\
\cline { 2 - 7 } & Dir &,- 088 &, 095 &,- 174 &,- 917 &, 367 \\
\hline
\end{tabular}

Source: SPSS output

Table-6 shows that the number of commissioners has a significant negative effect while the number of directors does not have a significant effect on the profitability of Sharia banks.

From these findings, it can be explained that the more the number of boards of commissioners, the impact on decreasing profitability. The board of commissioners is tasked with overseeing the work carried out by management so as not to run Sharia bank operations that are not as they should be. However, this research proves that management actually shows rigidity in working so that supervision by the commissioner makes management work not flexible. This should not happen, because controlling is intended so that the work remains in the corridor of rules and standards set by the management of Sharia banks.

This research was conducted at five Sharia commercial banks that have the largest assets. Therefore, better supervision is needed compared to other Sharia commercial banks, because the assets owned by Sharia banks must be managed as well as possible in order to obtain maximum profits.

The results of this study are important because there are differences in results from previous studies, that in Sharia banks that have large assets, the truth is that the board of commissioners does not have a good impact on improving financial performance, on the contrary it has a negative effect.

While the number of boards of directors did not have any effect on improving financial performance. This is a finding that to improve the financial performance of Sharia banks is not seen from the number of boards of directors, but must improve the quality of its human resources so that management can run its operations as well as possible.

\section{CONCLUSIONS AND SUGGESTIONS}

Based on the research results and explanations above, a number of important findings are obtained, as follows:

1. The number of boards of directors has no influence on the profitability of Sharia commercial banks, therefore, what is more, important is that the board of directors must maintain the quality of the directors not on the quantity. It is clear that the quantity of the board of directors does not have any impact on profitability so that the greater number of boards of directors will provide inefficient HR costs.

2. The number of boards of commissioners has a negative effect on the profitability of Sharia commercial banks. This means that more and more commissioners have an unfavorable impact on the profitability of Sharia banks because there is an irregularity in management's work because it is monitored and there is also a large amount of HR costs that must be spent.

From the findings of this study, then some suggestions can be proposed as follows:

1. Research must be expanded by increasing the number of samples, or it can be done by census to all Sharia commercial banks.

2. A more complex model must be tested to find the best model considering the $\mathrm{R}$ square value that is not so large. 
Kurniawan; Saudi J Bus Manag Stud, Jan., 2020; 5(1): 26-31

\section{REFERENCES}

1. Chapra, M. U., \& Umar, H. (2002). Corporate Governance for Islamic Financial Institution, Jeddah: IRTI-IDB.

2. Kasmir. (2005). Bank dan Lembaga Keuangan Lainnya. Jakarta: PT Raja Grafindo Persada

3. Andiwarman, K. (2004). Bank Islam Analisis Fiqih dan Keuanagan. PT Raja Grafindo persada. Jakarta

4. Sukandar, P. P. (2014). Pengaruh Ukuran Dewan Direksi dan Dewan Komisaris serta Ukuran Perusahaan terhadap Kinerja Keuangan Perusahaan. Diponegoro Journal of Accounting, 3(3).

5. Rahmawati, I., Rikumahu, B., \& Dillak, V. J. (2017). Pengaruh Dewan Direksi, Dewan Komisaris, Komite Audit Dan Corporate Social Responsibility Terhadap Kinerja Keuangan
Perusahaan. Jurnal Akuntansi dan Ekonomi FE. UN PGRI Kediri, 2(2).

6. Chtourou, L., Marrachi, S., \& Bedard, J. (2001). Corporate Governance and Earning Management. Available online at www.ssrn.com

7. Hidayat, I. P., \& Firmansyah, I. (2017). Determinants of Financial Performance in The Indonesian Islamic Insurance Industry. Etikonomi, 16(1):1-12

8. Putra, B. P. D. (2016). Pengaruh dewan komisaris, proporsi komisaris independen, terhadap kinerja perusahaan. Jurnal Manajemen Teori dan Terapan| Journal of Theory and Applied Management, $8(2)$.

9. Love, I., \& Klapper, L. F. (2002). Corporate governance, investor protection, and performance in emerging markets. The World Bank. 